Randomized Trial

\title{
A Randomized, Double-Blind, Active Control Trial of Fluoroscopic Cervical Interlaminar Epidural Injections in Chronic Pain of Cervical Disc Herniation: Results of a 2-Year Follow-Up
}

Laxmaiah Manchikanti, MD ${ }^{1,2}$, Kimberly A. Cash, RT ${ }^{1}$, Vidyasagar Pampati, MSc ${ }^{1}$, Bradley W. Wargo, DO ${ }^{3}$, and Yogesh Malla, MD'

From: ${ }^{1}$ Pain Management Center of Paducah, Paducah, KY; and ${ }^{2}$ University of Louisville, Louisville,

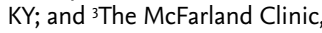
Mary Greeley Medical Center, Ames, lowa.

Dr. Manchikanti is Medical Director of the Pain Management Center of Paducah, Paducah, KY, and Clinical Professor, Anesthesiology and Perioperative Medicine, University of Louisville,

Louisville, KY. Ms. Cash is a Research Coordinator at the Pain Management Center of Paducah, Paducah, KY. Pampati is a Statistician at the Pain Management Center of Paducah,

Paducah, KY. Dr. Wargo is an Interventional Pain Physician at the McFarland Clinic, Mary Greeley Medical Center, Ames, IA. Dr. Malla is an Interventiona Pain Physician at the Pain Management Center of Paducah, Paducah, KY.

Address Correspondence: Laxmaiah Manchikanti, MD 2831 Lone Oak Road

Paducah, Kentucky 42003 E-mail:drlm@thepainmd.com

Disclaimer: There was no external funding in the preparation of this manuscript.

Conflict of interest: Each autho certifies that he or she, or a member of his or her immediate

family, has no commercial association, (i.e., consultancies, stock ownership, equity interest, patent/licensing arrangements, etc.) that might post a conflict of interest in connection with the submitted manuscript.

Manuscript received: 08-15-2013 Accepted for publication: 09-05-2013

Free full manuscript: www.painphysicianjournal.com
Background: A recent evaluation of the state of U.S. health from 1990 to 2010 placed neck pain as the fourth condition leading to disability, with low back pain being the number one. Multiple treatment modalities have been described in managing neck and upper extremity pain secondary to cervical disc herniation after the failure of conservative management. The treatment modalities for chronic persistent pain of cervical disc herniation include surgery and epidural injections. The growth of interventional techniques in managing chronic spinal pain in recent years has been enormous. Evidence for the efficacy of cervical interlaminar epidural injections, however, continues to be debated, despite positive evidence derived from controlled randomized trials and systematic reviews.

Study Design: A randomized, double-blind, active control trial.

Setting: A private, specialty referral, interventional pain management practice in the United States.

Objectives: To evaluate the effectiveness of epidural injections in managing chronic pain related to cervical disc herniation.

Methods: Patients were randomly assigned to one of 2 groups of 60, with a total of 120 patients. Group I patients received cervical epidural injections with lidocaine $0.5 \%$ preservative-free, $5 \mathrm{~mL}$, whereas Group II patients received $0.5 \%$ preservative-free lidocaine mixed with $1 \mathrm{~mL}$ or $6 \mathrm{mg}$ of non-particulate betamethasone.

Outcome Assessment: Multiple outcome measures included the numeric rating pain scale (NRS), the Neck Disability Index (NDI), employment status, opioid intake with assessment at 3, 6, 12, 18 , and 24 months post treatment.

Significant improvement was described as pain relief with a $50 \%$ improvement in functional status.

Results: This evaluation showed significant improvement as $50 \%$ pain relief and improvement in functional status in $72 \%$ of the patients at 2 year follow-up in the local anesthetic group and $68 \%$ in those patients receiving local anesthetic and steroid. In the successful group of participants however, significant improvement was seen in $77 \%$ in Group I and $80 \%$ in Group II.

Overall, the average number of procedures was 5 to 6 in both groups per 2 years. The average total relief for 2 years was $75.9 \pm 29.9$ weeks in Group I and $72.7 \pm 31.1$ in Group II, the successful group of participants. Taking into consideration all of the participants, the average total relief for 2 years was $69.6 \pm 35$ weeks in Group I and $62.1 \pm 38.4$ weeks in Group II.

Limitations: The results of the study are limited by the lack of a placebo group.

Conclusion: Cervical epidural injections with local anesthetic with or without steroids may offer significant benefit to patients suffering with chronic, persistent pain and disability related to cervical disc herniation.

Key words: Chronic neck pain, cervical disc herniation, upper extremity pain, cervical epidural injections, epidural steroids, local anesthetics

Trial Registration: NCT01071369

Pain Physician 2013; 16:465-478 


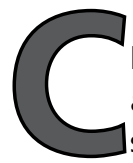
hronic neck pain is common in the general adult population with persistent complaints seen in $22 \%$ of women and $16 \%$ of men $(1,2)$. Moreover, the impact of chronic neck pain on general health showed $14 \%$ of patients reporting Grade II to IV neck pain with high pain intensity with disability (310). Furthermore, Grade III and IV pain with disability are seen in $5 \%$ of patients (3). In fact, a recent report describing the state of health in the U.S. from 1990 to 2010 showed that neck pain is the fourth condition leading to disability, with low back pain being the number one (11). In addition, Martin et al $(12,13)$, in assessing the effect of chronic spinal pain on the U.S. economy, found that costs were approximately $\$ 86$ billion, with an increase of $65 \%$ between 1997 and 2005 , and a $49 \%$ increase in the number of patients seeking spine related care. Furthermore, the Institute of Medicine (IOM) report on relieving pain in America (14), based on Gaskin and Richard (15), estimated the total economic cost of pain in the United States in 2010 to range from $\$ 560$ to $\$ 635$ billion. Of this, with the isolation of moderate and severe pain and eliminating other conditions, the costs appear to be approximately $\$ 100$ billion per year. Disability secondary to chronic pain also continues to increase (16).

Structures causing neck and upper extremity pain and headache include cervical intervertebral disc, cervical facet joints, ligaments, fascia, muscles, and nerve root dura, which are capable of transmitting pain (1719). Cervical radicular pain is pain perceived in the upper extremity, shooting or electric in quality, caused by irritation and/or injury of cervical spinal nerves $(19,20)$. Cervical radicular pain may be caused either by disc herniation or compression due to other ailments in the cervical spine, or chemical irritation (18-24).

Multiple treatment modalities have been described in managing neck and upper extremity pain secondary to cervical disc herniation after the failure of conservative management (25). The common treatment modalities for the chronic persistent pain of cervical disc herniation are related to surgery or epidural injections $(17,18,20,26-36)$. Along with escalating growth of surgical interventions $(26,27,32-36)$, cervical epidural injections also have shown intense growth, though less than in the lumbar spine (29-31). In an assessment of the growth of epidural injections in the fee-for-service Medicare population from 2000 to 2011 (31), it was shown that overall, epidural injections increased $130 \%$ per 100,000 Medicare beneficiaries with an annual increase of $7.5 \%$. The increases per 100,000 Medicare recipients were $123 \%$ for cervical/thoracic interlaminar epidural injections and $142 \%$ for cervical/thoracic transforaminal epidural injections. The increases were $665 \%$ for lumbosacral transforaminal epidural injections (31).

Evidence for the efficacy of cervical interlaminar epidural injections continues to be debated, even though evidence is derived from controlled randomized trials $(17,18)$. Diwan et al $(18)$, in a systematic review, identified 13 studies, utilizing 4 randomized trials assessing cervical disc herniation (37-41) meeting inclusion criteria for methodological quality assessment. Based on this review, they concluded that for cervical disc herniation, the evidence is good for cervical epidural with local anesthetic and steroids; whereas, it is fair with local anesthetic only. Among all the studies included in the evidence assessment for disc herniation, the study by Manchikanti et al $(37,38)$ included 120 patients with an active control design and showed significant improvement with pain and function of $50 \%$ or more in $72 \%$ of the patients who received local anesthetic only and $68 \%$ who received local anesthetic and steroids. Furthermore, in the successful group of participants, significant improvement was illustrated in $77 \%$ of the local anesthetic group and $82 \%$ of the local anesthetic with steroid group.

The current study was undertaken to evaluate the role of cervical interlaminar epidural injections with local anesthetic or with local anesthetic and steroids in patients with disc herniation suffering with chronic function-limiting neck and upper extremity pain. The study was designed to be a randomized double-blind, active-control with 120 patients with 60 patients in each group. The preliminary report and one year follow-up of this study were published $(37,38)$.

\section{Methods}

The design of the study was a randomized, doubleblind, active control trial. The study was conducted based on the Consolidated Standards of Reporting Trials (CONSORT) guidelines $(42,43)$. The study was performed in an interventional pain management practice, tertiary referral center in the United States. The protocol was approved by the Institutional Review Board (IRB) and was registered with the U.S. Clinical Trial Registry with an assigned number of (NCT01071369). This trial was conducted with internal resources of the practice without external funding.

\section{Participants}

All study participants were derived from new 
patients presenting to the interventional pain management practice. All the patients were provided with IRB approved protocol, as well as informed consent, which described in detail various aspects of the trial and withdrawal process.

\section{Interventions}

Of the 120 patients included in the trial, 60 were assigned to each group. Thus, Group I patients received cervical interlaminar epidural injections of local anesthetic only with lidocaine $0.5 \%, 5 \mathrm{~mL}$, preservative-free. In contrast, Group II patients received cervical interlaminar epidural injections with $0.5 \%$ lidocaine, $4 \mathrm{~mL}$, mixed with $1 \mathrm{~mL}$ or $6 \mathrm{mg}$ of non-particulate betamethasone with a total volume of $5 \mathrm{~mL}$ of injectate.

\section{Pre-Enrollment Evaluation}

Prior to the enrollment in the trial, baseline demographic data were collected. This included demographics, medical and surgical history with co-existing disease(s), radiological investigations including magnetic resonance imaging and/or computed tomography, nerve conduction studies, physical assessment results, Numeric Rating Scale (NRS) pain scores, and functional status assessment scores utilizing Neck Disability Index (NDI). Additional information included work status, opioid intake, other drug therapy, and the details of conservative management.

\section{Inclusion Criteria}

Only patients with cervical disc herniation with or without radiculitis were included. Patients of at least 18 years of age with chronic, function-limiting neck and upper extremity pain of at least 6 months duration were included. All patients must have been competent to understand the study protocol, provide voluntary informed consent, and participate in outcome measures. Additional criteria were that all patients have utilized conservative treatment modalities, including, but not limited to, physical therapy, a structured exercise program, and drug therapy.

However, any patient with cervical spine surgery, radiculitis secondary to spinal stenosis, discogenic pain without disc herniation, uncontrollable or unstable opioid use, uncontrolled psychiatric disorders, and uncontrolled medical illness were excluded. Additional exclusion criteria included any condition that could interfere with the interpretation of the outcome assessment, pregnancy and lactation or a history of adverse reactions to local anesthetic or steroids.

\section{Description of Interventions}

Cervical interlaminar epidural injections were performed by one physician in an ambulatory surgery center, in a sterile operating room, under fluoroscopy. All patients were positioned in the prone position, appropriate monitors were applied, and intravenous access along with sedation with midazolam and fentanyl were utilized whenever indicated.

The epidural space was entered with the loss of resistance technique under fluoroscopic visualization between $\mathrm{C} 7$ and $\mathrm{T} 1$ to $\mathrm{C} 5$ and $\mathrm{C} 6$ with confirmation by injection of non-ionic contrast medium. After confirmation of the location of the needle in the epidural space with appropriate contrast spread, solutions were injected into the epidural space with a total of $5 \mathrm{~mL}$ mixture.

Repeat cervical epidural injections were only provided based on the response to prior cervical epidural injections. The response was assessed by improvement in physical and functional status, with repeat procedures provided when increased levels of pain were reported with deterioration of functional status and pain relief to below $50 \%$.

\section{Co-interventions}

All patients received continued drug therapy with opioids or nonopioid analgesics, therapeutic exercise program, normal activities, and work. The total drug therapy was reduced in a majority of patients. In addition, there was no specific physical therapy, occupational therapy, or other interventions to any of the patients.

\section{Objectives}

This assessment was designed to evaluate the effectiveness of cervical interlaminar epidural injections performed under fluoroscopy utilizing local anesthetic with or without steroids in managing chronic recalcitrant neck and upper extremity pain secondary to disc herniation.

\section{Outcomes}

Multiple outcome measures were utilized. The primary outcome measure was combined improvement in pain scores and functional status improvement. Significant improvement was defined as at least 50\% pain relief associated with at least $50 \%$ improvement in functional status as measured by NRS and NDI. This is a robust measure of improvement when compared to previous parameters of minimum clinically important 
difference (MCID) (44-48). In addition, the NRS and NDI have been shown to be valid and reliable in patients with mechanical neck pain $(49,50)$.

Opioid intake was measured in conversion units for morphine equivalency (51). The changes in intake were assessed based on these criteria in terms of morphine equivalence based on the dosage, frequency, and schedule of the drug.

Employment was also measured in both groups. Employment was based on patients who were employable and those who were not employable. Employable patients were selected based on their unemployment and employment status either on a part-time or a fulltime basis. However, patients who chose not to work, were retired, or were homemakers without the necessity or desire to work outside the home, but not due to pain, were considered as not employable. Consequently, these were not included in the employment pool.

\section{Sample Size}

The sample size was calculated based on significant pain relief. Consequently, a 0.05 two-sided significance level, a power of $80 \%$, and an allocation ratio of $1: 1$, was utilized, yielding an estimated 55 patients in each group (52). Subsequently while allowing for a $10 \%$ attrition or non-compliance rate, it was estimated that 60 patients in each group were required.

\section{Randomization}

Of the 120 patients, 60 patients were randomly assigned into Group I, whereas another 60 were assigned into Group II.

\section{Sequence Generation}

A simple randomization formula was utilized with a computer-generated random allocation sequence.

\section{Allocation Concealment}

The patients were randomized into 2 groups by one of the 3 trial coordinators. The drugs were appropriately prepared as to mask any identification of them.

\section{Blinding (Masking)}

Various measures were undertaken to secure appropriate blinding and masking. The group assignment was blinded to all involved, including the physician and the patients. Furthermore, both solutions were clear, not allowing identification of the group assignment. As an extra measure, all study patients were mixed with the other patients receiving routine treatments. Neither the physician performing the procedure nor the patient receiving the procedure were informed of group assignment or the nature of the study participation.

\section{Statistical Methods}

Data analyses were carried out using SPSS version 9.01 (SPSS Inc, Chicago, IL). For categorical and continuous data comparison, Chi-squared statistic, Fisher's exact test, one-way analysis of variance, Student's t-test, and paired t-test were used. Because the outcome measures of the participants were measured at 6 time points, repeated measures analysis of variance were performed with post hoc analysis. A P value of less than 0.05 was considered significant.

A statistical significance was considered as a $P$ value of 0.05 .

\section{Intent-to-Treat-Analysis}

An intent-to-treat analysis was performed utilizing either the last follow-up data or initial data for the patients withdrawn. In addition, sensitivity analysis utilizing best case, worst case, and last follow-up data was performed.

\section{Results}

\section{Patient Flow}

Figure 1 illustrates the patient flow. The recruitment period started in August 2007 and ended in June 2010.

\section{Demographic Data}

Baseline demographic and clinical characteristics for Group I and II are illustrated in Table 1. While there were no significant differences in the majority of the parameters, Group I patients weighed significantly more than Group II patients.

\section{Pain Relief and Functional Assessment}

Pain relief scores and functional assessment results are shown in Table 2.

The proportion of patients with a significant reduction in the NRS and NDI with greater than $50 \%$ reduction from baseline is illustrated in Figure 2. Successful patients, defined as those with the initial 2 procedures had at least 3 weeks of relief showed better results compared to all patients at 24 months, with an improvement of $72 \%$ in Group I and $68 \%$ in Group II for all patients compared to $77 \%$ and $80 \%$ in the successful groups. 


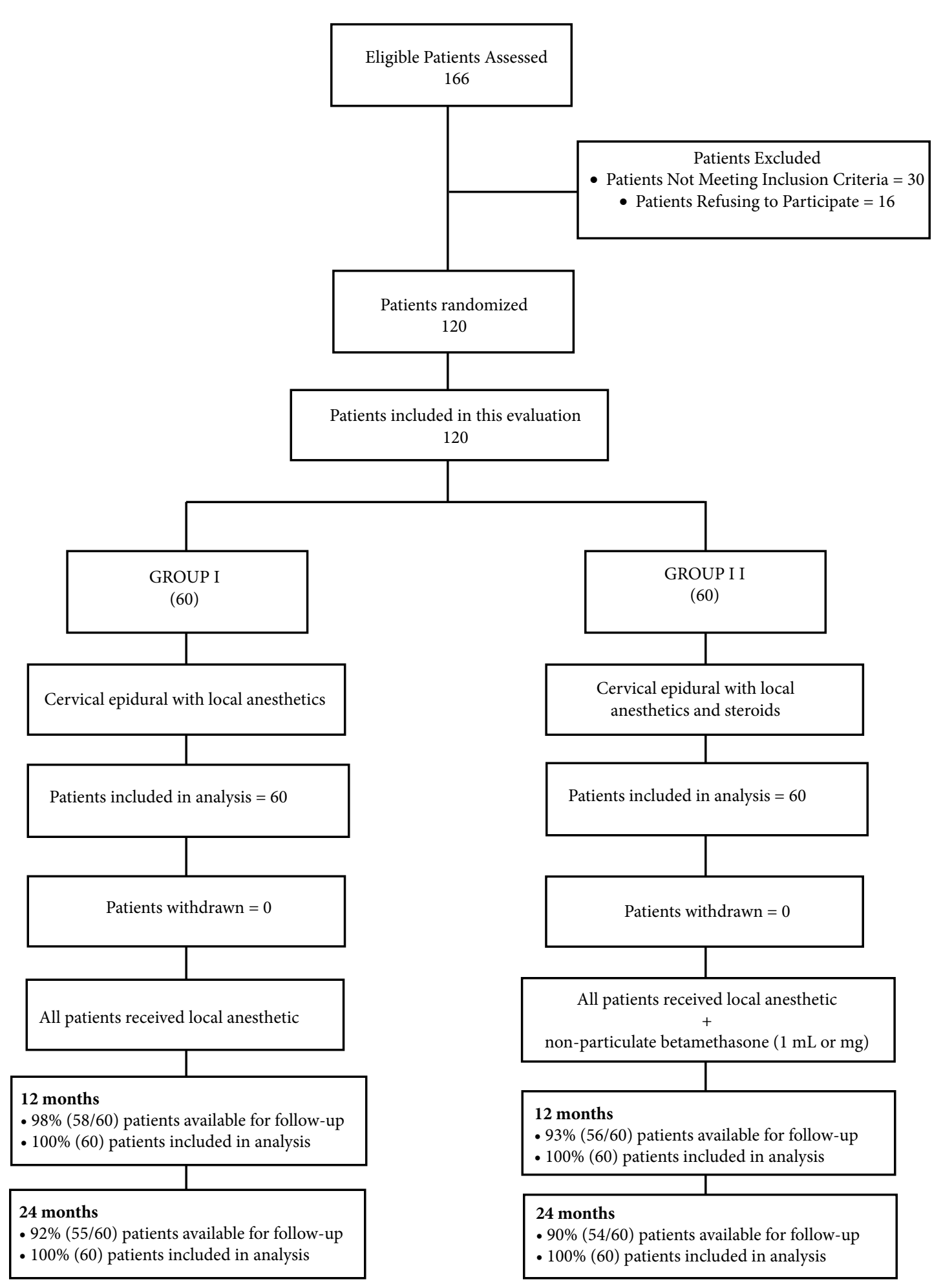

Fig. 1. Schematic presentation of patient flow at 2-years follow-up. 
Table 1. Baseline demographic characteristics.

\begin{tabular}{|c|c|c|c|c|}
\hline & & $\begin{array}{c}\text { Group } 1 \\
(60)\end{array}$ & $\begin{array}{c}\text { Group II } \\
(60)\end{array}$ & $P$ value \\
\hline \multirow{2}{*}{ Gender } & Male & $47 \%(28)$ & $42 \%(25)$ & \multirow{2}{*}{0.581} \\
\hline & Female & $53 \%(32)$ & $58 \%(35)$ & \\
\hline Age & Mean \pm SD & $46.2 \pm 10.3$ & $45.6 \pm 10.4$ & 0.738 \\
\hline Weight & Mean \pm SD & $208.9 \pm 53.3$ & $168.1 \pm 35.2$ & 0.000 \\
\hline Height & Mean \pm SD & $67.3 \pm 4.4$ & $66.3 \pm 4.0$ & 0.199 \\
\hline Duration of Pain (months) & Mean \pm SD & $118.3 \pm 98.6$ & $91.9 \pm 94.5$ & 0.137 \\
\hline \multirow{2}{*}{ Onset of the Pain } & Gradual & $53 \%(32)$ & $52 \%(31)$ & \multirow{2}{*}{0.855} \\
\hline & Injury & $47 \%(28)$ & $48 \%(29)$ & \\
\hline \multirow{4}{*}{ Neck Pain Distribution } & Neck pain only & $15 \%(9)$ & $17 \%(10)$ & \multirow{4}{*}{0.975} \\
\hline & Neck pain worse than upper extremity & $57 \%(34)$ & $55 \%(33)$ & \\
\hline & Upper extremity worse than neck pain & $8 \%(5)$ & $7 \%(4)$ & \\
\hline & Both equal & $20 \%(12)$ & $21 \%(13)$ & \\
\hline \multirow{5}{*}{$\begin{array}{l}\text { Disc Herniation Levels } \\
\text { (at multiple levels) }\end{array}$} & $\mathrm{C} 3 / 4$ & $13 \%(8)$ & $13 \%(8)$ & \multirow{5}{*}{0.550} \\
\hline & $\mathrm{C} 4 / 5$ & $30 \%(18)$ & $20 \%(12)$ & \\
\hline & $\mathrm{C} 5 / 6$ & $50 \%(30)$ & $60 \%(36)$ & \\
\hline & $\mathrm{C} 6 / 7$ & $40 \%(24)$ & $47 \%(28)$ & \\
\hline & C7/T1 & $10 \%(6)$ & $12 \%(7)$ & \\
\hline Numeric Rating Score & Mean \pm SD & $7.9 \pm 1.0$ & $7.9 \pm 0.9$ & 1.000 \\
\hline Neck Disability Index & Mean \pm SD & $29.6 \pm 5.3$ & $29.2 \pm 6.1$ & 0.678 \\
\hline
\end{tabular}

Table 2. Comparison of Numeric Rating Scale for pain and Neck Disability Index score summaries.

\begin{tabular}{|c|c|c|c|c|}
\hline \multirow[t]{2}{*}{ Time Points } & \multicolumn{2}{|c|}{$\begin{array}{c}\text { Numeric Pain Rating Score } \\
\text { Mean } \pm \text { SD }\end{array}$} & \multicolumn{2}{|c|}{$\begin{array}{c}\text { Neck Disability Index } \\
\text { Mean } \pm \text { SD }\end{array}$} \\
\hline & Group I (N=60) & Group II (N=60) & Group I (N=60) & Group II $(\mathrm{N}=60)$ \\
\hline Baseline & $7.9 \pm 1.0$ & $7.9 \pm 0.9$ & $29.6 \pm 5.3$ & $29.2 \pm 6.1$ \\
\hline 3 months & $\begin{array}{l}3.7^{*} \pm 1.4 \\
(85 \%)\end{array}$ & $\begin{array}{l}3.8^{*} \pm 1.4 \\
(75 \%)\end{array}$ & $\begin{array}{l}14.7^{*} \pm 5.5 \\
\quad(85 \%)\end{array}$ & $\begin{array}{l}15.6^{*} \pm 6.3 \\
\quad(70 \%)\end{array}$ \\
\hline 6 months & $\begin{array}{c}3.5^{*} \pm 1.4 \\
(83 \%)\end{array}$ & $\begin{array}{l}3.9^{*} \pm 1.5 \\
(73 \%)\end{array}$ & $\begin{array}{c}13.8^{*} \pm 5.4 \\
\quad(83 \%)\end{array}$ & $\begin{array}{l}15.3^{*} \pm 6.9 \\
(73 \%)\end{array}$ \\
\hline 12 months & $\begin{array}{l}3.7^{*} \pm 1.5 \\
(72 \%)\end{array}$ & $\begin{array}{l}3.9^{*} \pm 1.5 \\
(72 \%)\end{array}$ & $\begin{array}{l}13.8^{*} \pm 5.7 \\
\quad(75 \%)\end{array}$ & $\begin{array}{l}15.1^{*} \pm 7.0 \\
(68 \%)\end{array}$ \\
\hline 18 months & $\begin{array}{c}3.6^{*} \pm 1.6 \\
(75 \%)\end{array}$ & $\begin{array}{c}3.6^{*} \pm 1.5 \\
(72 \%)\end{array}$ & $\begin{array}{c}13.7^{*} \pm 5.5 \\
(77 \%)\end{array}$ & $\begin{array}{c}14.7^{*} \pm 6.8 \\
(72 \%)\end{array}$ \\
\hline 24 months & $\begin{array}{l}3.8^{*} \pm 1.6 \\
(72 \%)\end{array}$ & $\begin{array}{l}3.8^{*} \pm 1.7 \\
(68 \%)\end{array}$ & $\begin{array}{l}13.7^{*} \pm 5.7 \\
\quad(73 \%)\end{array}$ & $\begin{array}{l}14.3^{*} \pm 6.9 \\
(70 \%)\end{array}$ \\
\hline Group Difference & \multicolumn{2}{|c|}{0.645} & \multicolumn{2}{|c|}{0.466} \\
\hline Baseline vs follow-up points & \multicolumn{2}{|c|}{0.001} & \multicolumn{2}{|c|}{0.001} \\
\hline Group by Time Interaction\# & \multicolumn{2}{|c|}{0.350} & \multicolumn{2}{|c|}{0.416} \\
\hline
\end{tabular}

Percentages in parenthesis illustrates proportion with significant pain relief $(\geq 50 \%)$ from baseline

* indicates significant difference with baseline values $(\mathrm{P}<0.01)$ with in the group

\# Group by Time Interaction - There was no significant difference between groups at 3 months, 6 months, 12 months, 18 months, and 24 months 


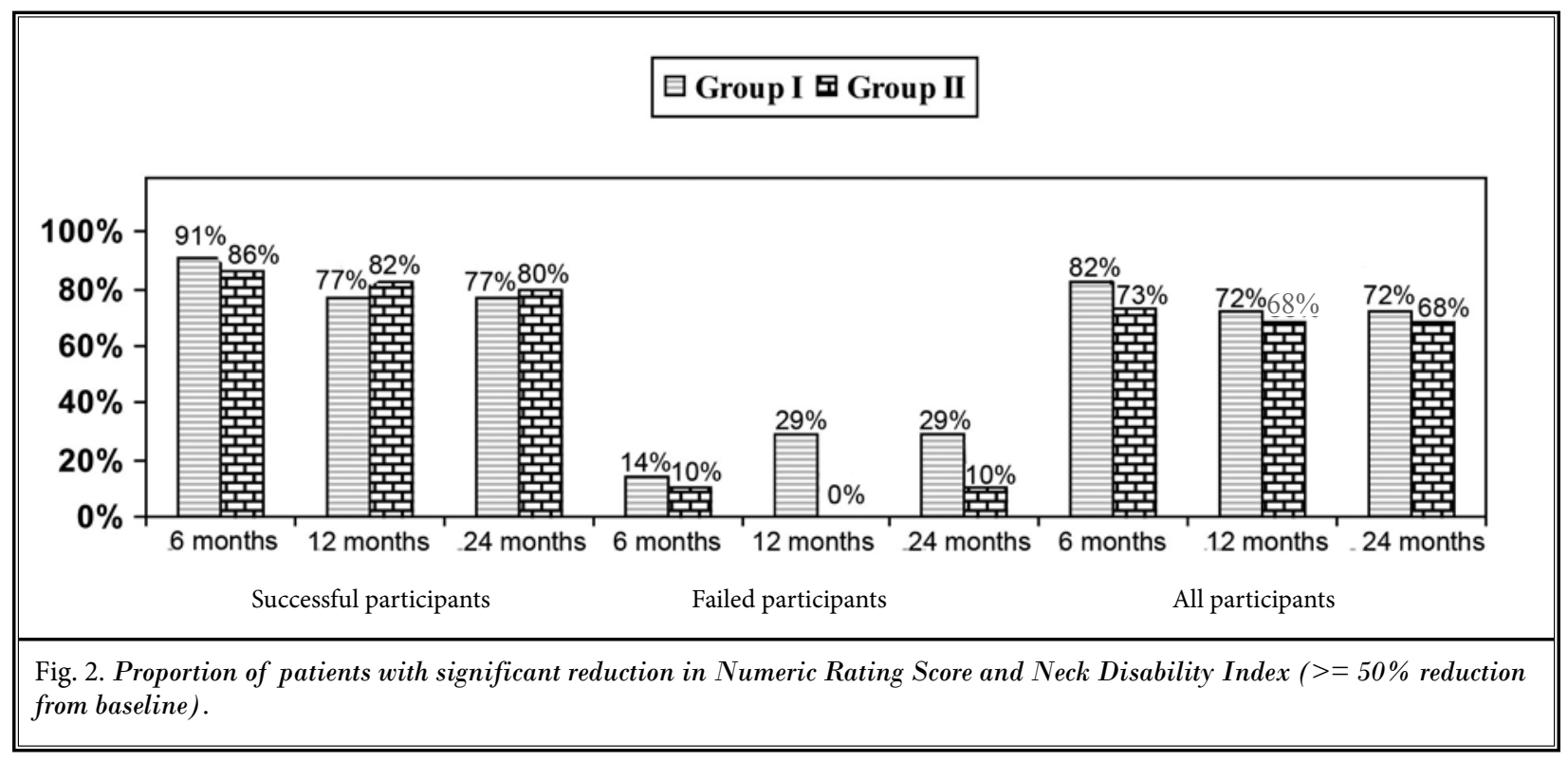

Table 3. Therapeutic procedural characteristics with procedural frequency, average relief per procedure, and average total relief in weeks over a period of 2 years.

\begin{tabular}{|l|c|c|c|c|c|c||}
\hline & \multicolumn{2}{|c|}{ Successful Participants } & \multicolumn{2}{|c||}{ Failed Participants } & \multicolumn{2}{|c|}{ All Participants } \\
\hline & $\begin{array}{c}\text { Group I } \\
\mathbf{( 5 3 )}\end{array}$ & $\begin{array}{c}\text { Group II } \\
\mathbf{( 5 0 )}\end{array}$ & $\begin{array}{c}\text { Group I } \\
(\mathbf{7})\end{array}$ & $\begin{array}{c}\text { Group II } \\
(\mathbf{1 0})\end{array}$ & $\begin{array}{c}\text { Group I } \\
(\mathbf{6 0 )}\end{array}$ & $\begin{array}{c}\text { Group II } \\
(\mathbf{6 0})\end{array}$ \\
\hline Average number of procedures for one year & $3.7 \pm 1.1$ & $3.7 \pm 1.2$ & $2.7 \pm 1.5$ & $2.0 \pm 1.2$ & $3.6 \pm 1.2$ & $3.4 \pm 1.3$ \\
\hline Average number of procedures for 2 years & $5.8 \pm 2.5$ & $5.9 \pm 2.4$ & $3.7 \pm 3.1$ & $2.4 \pm 2.4$ & $5.6 \pm 2.7$ & $5.3 \pm 2.7$ \\
\hline $\begin{array}{l}\text { Average relief per procedure for initial 2 } \\
\text { procedures in weeks }\end{array}$ & $9.8 \# \pm 7.9$ & $7.8 \pm 8.1$ & $0.8 \pm 1.1$ & $0.5 \pm 0.6$ & $8.8 \pm 8.0$ & $6.8 \pm 7.9$ \\
\hline $\begin{array}{l}\text { Average relief per procedure after initial 2 } \\
\text { procedures }\end{array}$ & $13.5 \pm 6.5$ & $12.5 \pm 3.4$ & $7.7 \pm 5.5$ & $8.8 \pm 5.3$ & $13.1 \pm 6.6$ & $12.3 \pm 3.5$ \\
\hline Average relief per procedure & $13.2 \pm 11.0$ & $12.5 \pm 10.7$ & $5.9 \pm 5.9$ & $3.9 \pm 5.4$ & $12.6 \pm 10.9$ & $11.8 \pm 10.6$ \\
\hline Average total relief for one year (weeks) & $41.4 \pm 12.7$ & $36.3 \pm 14.6$ & $9.0 \pm 13.4$ & $4.2 \pm 10.9$ & $37.6 \# \pm 16.4$ & $31.0 \pm 18.5$ \\
\hline Average total relief for 2 years (weeks) & $75.9 \pm 29.9$ & $72.7 \pm 31.1$ & $21.9 \pm 35.6$ & $9.2 \pm 26.6$ & $69.6 \pm 35.0$ & $62.1 \pm 38.4$ \\
\hline
\end{tabular}

\# indicates significant difference with Group II $(P<0.05)$

\section{Therapeutic Procedural Characteristics}

Epidural entry was performed between $\mathrm{C} 7$ and T1 in $28 \%$ of patients, between $\mathrm{C} 6$ and $\mathrm{C} 7$ in $60 \%$ of patients, and between $\mathrm{C} 5$ and $\mathrm{C} 6$ in $12 \%$ of patients as shown in Table 1. Therapeutic procedural characteristics are illustrated in Table 3.

Average relief per 2 years showed no significant differences: $69.6 \pm 35.0$ weeks in Group I and 62.1 \pm 38.4 weeks in Group II. The total number of injections per 2 years was $5.6 \pm 2.7$ in Group I and $5.3 \pm 2.7$ in Group II. However, when patients were separated into successful and failed groups, the total number of injections per 2 years was $5.8 \pm 2.5$ in Group I and $5.9 \pm 2.4$ in Group II in the successful groups, and $3.7 \pm 3.1$ for Group I and $2.4 \pm 2.4$ for Group II in the failed groups. Total relief for 2 years of 75.9 weeks was obtained in the successful group in Group I; in Group II it was 72.7 weeks. In contrast, the relief was 21.9 weeks in Group I and 9.2 weeks in Group II for the failed groups.

The initial therapy was considered to be successful if a patient obtained consistent relief with 2 initial injections lasting at least 3 weeks. All others were considered failures. 
Table 4. Employment characteristics.

\begin{tabular}{|l|c|c|c|c|c|c||}
\hline \multirow{2}{*}{ Employment status } & \multicolumn{3}{|c|}{ Group I } & \multicolumn{3}{c|}{ Group II } \\
\cline { 2 - 8 } & Baseline & $\mathbf{1 2}$ months & 24 months & Baseline & 12 months & 24 months \\
\hline Employed part-time & 2 & 2 & 3 & 2 & 3 & 2 \\
\hline Employed full-time & 9 & 9 & 9 & 13 & 14 & 17 \\
\hline Unemployed (due to pain) & 0 & 0 & 0 & 2 & 1 & 0 \\
\hline Not working & 2 & 2 & 2 & 5 & 4 & 4 \\
\hline Eligible for employment at Baseline & 13 & 13 & 13 & 22 & 22 & 22 \\
\hline Total Employed & 11 & 11 & 12 & 15 & 17 & 19 \\
\hline Housewife & 3 & 3 & 3 & 1 & 1 & 1 \\
\hline Disabled & 37 & 37 & 36 & 33 & 33 & 32 \\
\hline Retired & 7 & 7 & 7 & 4 & 4 & 4 \\
\hline Total Number of Patients & 60 & 60 & 60 & 60 & 60 & 60 \\
\hline
\end{tabular}

Table 5. Opioid intake (morphine equivalence mg).

\begin{tabular}{|c|c|c|}
\hline \multirow{2}{*}{$\begin{array}{l}\text { Opioid intake } \\
\text { (Morphine Equivalence mg) }\end{array}$} & Group I (60) & Group II (60) \\
\hline & Mean \pm SD & Mean \pm SD \\
\hline Baseline & $57.0 \pm 46.1$ & $53.8 \pm 36.1$ \\
\hline 3 months & $34.4^{\star} \pm 21.7$ & $35.2^{*} \pm 16.3$ \\
\hline 6 months & $33.0^{\star} \pm 22.3$ & $35.5^{\star} \pm 16.3$ \\
\hline 12 months & $34.7^{\star} \pm 23.5$ & $35.5^{\star} \pm 16.3$ \\
\hline 18 months & $35.8^{\star} \pm 24.9$ & $32.0^{*} \pm 18.9$ \\
\hline 24 months & $35.8^{*} \pm 24.9$ & $31.3^{*} \pm 19.1$ \\
\hline Group difference & \multicolumn{2}{|c|}{0.614} \\
\hline Baseline vs follow-up points & \multicolumn{2}{|c|}{0.001} \\
\hline Group by time interaction\# & \multicolumn{2}{|c|}{0.623} \\
\hline
\end{tabular}

${ }^{*}$ indicates significant difference with baseline values $(P<0.01)$

\# Group by Time Interaction - There was no significant difference be-

tween groups at 3, 6, 12, 18 and 24 months

\section{Employment Characteristics}

Table 4 shows the employment characteristics in both groups.

\section{Opioid Intake}

The results of opioid intake and changes in opioid intake are shown in Table 5.

\section{Changes in Weight}

Table 6 shows changes in weight, either with gain or loss.

\section{Adverse Events}

Of the 654 procedures performed, there were 2 subarachnoid punctures, 4 intravascular penetrations, 5 nerve root irritations, and one report of soreness
Table 6. Characteristics of changes in weight.

\begin{tabular}{|c|c|c|c|}
\hline \multirow{2}{*}{ Weight (lbs) } & Group I (60) & Group II (60) & \multirow{2}{*}{$\begin{array}{c}P \\
\text { value }\end{array}$} \\
\hline & Mean \pm SD & Mean \pm SD & \\
\hline Weight at Beginning & $208.9 \pm 53.3$ & $168.1 \pm 35.2$ & 0.000 \\
\hline Weight at one year & $205.4 \pm 53.6$ & $166.9 \pm 32.7$ & 0.000 \\
\hline Change & $-3.5 \pm 9.9$ & $-1.1 \pm 7.4$ & 0.139 \\
\hline Lost weight & $57 \%(34)$ & $43 \%(26)$ & \multirow{3}{*}{0.311} \\
\hline No change & $20 \%(13)$ & $25 \%(15)$ & \\
\hline Gained weight & $22 \%(13)$ & $32 \%(19)$ & \\
\hline Weight at 2 years & $205.5 \pm 53.9$ & $167.7 \pm 33.26$ & 0.000 \\
\hline Change & $-3.4 \pm 11.8$ & $-0.35 \pm 10.89$ & 0.000 \\
\hline Lost weight & $53 \%(32)$ & $35 \%(21)$ & \multirow{3}{*}{0.123} \\
\hline No change & $15 \%(9)$ & $23 \%(25)$ & \\
\hline Gained weight & $32 \%(19)$ & $42 \%(25)$ & \\
\hline
\end{tabular}

lasting one week. No postoperative headache was reported after subarachnoid punctures.

\section{Discussion}

The present randomized, double-blind, controlled trial of 120 patients with cervical disc herniation showed significant improvement with local anesthetics with or without steroids performed under fluoroscopic guidance. In this active control design $72 \%$ of patients in the local anesthetic group and $68 \%$ of patients in the local anesthetic with steroids group showed significant improvement with at least $50 \%$ improvement in pain and disability at 2-year follow-up. Significant improvement utilized here is a robust outcome measure compared to previous measures of $20 \%$ or $30 \%$ improvement in one or both parameters (44-46). In addition, in selected 
patients, defined as successful participants, with those responding to the first 2 initial procedures with at least 3 weeks of improvement, significant improvement was seen in $77 \%$ in Group I and $88 \%$ in Group II at 2-year follow-up. Thus, the long-term follow-up of a large proportion of patients administered with cervical interlaminar epidural injections under fluoroscopy in a contemporary interventional pain management setting confirms that the treatment of cervical disc herniation and radiculitis shows a significant clinical effect. This study also showed overall average procedures per 2 years of 5.6 in Group I and 5.3 in Group II, with an average total relief per 2 years of 69.6 weeks for Group I patients and 62.1 weeks for Group II patients from a total of 104 weeks. The average total relief was higher in the successful group compared to overall patients. In addition, opioid intake was significantly reduced in both groups from the baseline.

The common causes of radicular pain and radiculopathy are disc protrusion, cervical spondylosis, or cervical spinal stenosis. Other causes include facet joint pathology, vertebral body pathology, meningeal pathology, and pathology from the involvement of blood vessels, nerve sheaths, and nerves $(17,19,20,22)$. Multiple mechanisms other than mechanical compressions have been described which included unique properties of spinal nerves and inflammatory mechanisms $(17,19,22-24,53,54)$. Furthermore, herniated cervical intervertebral discs have been shown to produce multiple potential irritants of spinal nerves causing inflammation $(20,22,24,53,54)$. Even though a large number of treatments have been described in managing the pain of cervical disc herniation, once the disc and resultant pain becomes recalcitrant and long lasting resulting in long-term disability, apart from surgical interventions, interventional pain management is the choice of treatment (17).

The primary goals of surgical interventions are to relieve radiating arm pain in the case of radiculopathy and to prevent progression of neurological deficit in case of myelopathy (27). Cervical epidural injections have been used to treat radicular pain from herniated discs, spinal stenosis, chronic pain secondary to post cervical surgery syndrome, and chronic neck pain of discogenic origin without disc herniation (17, 18,37-41,55-63).

Epidural injections in the cervical spine are performed either by the interlaminar or transforaminal routes; however, cervical transforaminal epidural injections are associated with high risk and are subject to intense debate (64-69). However, the interlaminar epidural injections are also associated with significant risk, though substantially less than that associated with transforaminal epidural injections (70-75). Despite these complications, cervical transforaminal epidural injections have increased $142 \%$ from 2000 to 2011 per 100,000 Medicare fee-for-service population (31). In contrast, cervical interlaminar epidural injections increased $123 \%$ over the same period (31); however, these increases are significantly less than cervical facet joint interventions, which showed increases of 359\% for cervical facet joint nerve blocks and $836 \%$ for neurolytic procedures (76). Consequently, all these increases are exponential and uncontrollable compared to lumbar interlaminar epidural injections which have shown a $25 \%$ increase over the same period (31). The majority of the literature describes cervical interlaminar epidural injections performed without fluoroscopy. In fact, surveys conducted in the past in reference to the technical aspects of epidural steroid injections showed only $39 \%$ of interlaminar epidural injections being performed under fluoroscopy in academic settings compared to $73 \%$ in private practice settings (77). Other studies have shown a significant proportion of procedures without entry into the epidural space without fluoroscopy (78). The major risk of cervical interlaminar epidural injection is the narrow epidural space leading to a higher incidence of discontinuity in the ligamentum flavum resulting in a higher rate of dural punctures $(71,79,80)$.

The results of this randomized trial are similar to the previous assessments as shown by Diwan et al (18) based on the preliminary assessment of this trial: There was good evidence in managing cervical disc herniation. The same was echoed in the comprehensive evidence-based spinal interventional techniques guidelines (17); however, results may not correlate with non-fluoroscopically performed cervical interlaminar epidural injections. There is no study with a large population of patients of 120, as in this study with 60 patients in each group with appropriate follow-up of clinical parameters for 2 years. Essentially the multiple studies in the past have been criticized for their design and inability to confirm the location as the majority of them were performed without fluoroscopy. Systematic reviews also have been criticized for their methodology by evaluating the studies inappropriately, reaching inaccurate conclusions $(81,82)$.

Even though epidural injections are extensively used in managing various types of spinal pain, the underlying mechanism of action of epidurally administered local anesthetics and steroids continues to be 
unclear. It has been hypothesized that the effects of neural blockade are dependent on various mechanisms for both local anesthetics and steroids, including antiinflammatory properties (83-87). The wide array of literature assessing the clinical and experimental nature of these drugs indicates that local anesthetic injections may provide relief similar to corticosteroids (88-93).

The strengths of this trial include its comparative evaluation which has become pivotal in modern evidence-based medicine (94-96). This study provided insight into not only the effectiveness of local anesthetic with or without steroids, but also successful and failed groups based on the first 2 procedures. The patients in the successful group, those who had good pain relief with first and second procedures, constituting over $80 \%$ of the enrolled patients, showed average relief from 72.7 to 75.6 weeks out of 104 weeks. In contrast, in the failed group, the average relief per procedure was 9.2 to 21.9 weeks, with overall relief of 62.1 to 69.6 weeks over a period of 2 years. Further, this study also revealed that there were no significant differences noted whether a steroid was utilized or not in the proportion of failed patients as well as the duration of relief. The same results carried on for all the patients over 2 year period. This is in contrast to lumbar disc herniation, which demonstrated a superiority of improvement in the steroid group with lumbar disc herniation both with caudal and lumbar interlaminar approaches at least in short term $(97,98)$. Further, in contemporary interventional pain management the procedures were repeated when the relief started deteriorating below $50 \%$ as per published guidelines $(17,18)$. Thus, this study embodies the practical nature of interventional pain management with an active control group instead of placebo group measuring the effectiveness and clinical importance which provides meaningful outcomes.

Nevertheless, limitations do include the lack of a placebo group. Having a placebo group designed with appropriate inclusion $(99,100)$ of injection of a placebo solution into a nonactive structure has been continuously debated $(17,18,81,82,100-106)$. Placebo interventions have been misinterpreted based on the solution injected and the location of the injection, with some even interpreting local anesthetic injection as placebo, not realizing the inactive substances injected into active structures invariably result in a multitude of effects, with the majority of them being therapeutic $(82,101-$ 109). The effects of placebo, nocebo, Hawthorne effect, natural course of the disease, which is not applicable in these chronic patients, and regression to the mean have been extensively discussed in reference to placebo, nocebo, and pure, impure, and fake placebo's (107-109). The only appropriate placebo designs reported in interventional pain management were those of Ghahreman et al (104) and Gerdesmeyer et al (110). These trials showed when proper placebo design is achieved, with injection of an inactive solution into inactive structure, it is not only considered to be a true placebo, but the results are striking in the treatment groups.

\section{Conclusion}

Fluoroscopically guided cervical interlaminar epidural injections of local anesthetic with or without steroids for chronic neck and upper extremity pain secondary to disc herniation and radiculitis illustrated effectiveness in $72 \%$ of patients in the local anesthetic group and $68 \%$ in the steroid group, with improvement in pain and functional status in the successful groups, requiring an average of 5.5 procedures over a 2-year period.

\section{Acknowledgments}

The authors wish to thank Alvaro F. Gómez, MA, and Laurie Swick, BS for manuscript review, and Tonie M. Hatton and Diane E. Neihoff, transcriptionists, for their assistance in preparation of this manuscript. We would like to thank the editorial board of Pain Physician for review and criticism in improving the manuscript. 


\section{References}

1. Hogg-Johnson S, van der Velde G, Carroll LJ, Holm LW, Cassidy JD, Guzman J, Côté P, Haldeman S, Ammendolia C, Carragee E, Hurwitz E, Nordin M, Peloso P; Bone and Joint Decade 20002010 Task Force on Neck Pain and Its Associated Disorders. The burden and determinants of neck pain in the general population: Results of the Bone and Joint Decade 2000-2010 Task Force on Neck Pain and Its Associated Disorders. Spine (Phila Pa 1976) 2008; 33:S39-S51.

2. Enthoven P, Skargren E, Oberg B. Clinical course in patients seeking primary care for back or neck pain: A prospective 5-year follow-up of outcome and health care consumption with subgroup analysis. Spine (Phila Pa 1976) 2004; 29:2458-2465.

3. Côté P, Cassidy JD, Carroll L. The Saskatchewan Health and Back Pain Survey. The prevalence of neck pain and related disability in Saskatchewan adults. Spine (Phila Pa 1976) 1998; 23:1689-1698.

4. Linton SJ, Hellsing AL, Hallden K. A population based study of spinal pain among 35-45-year old individuals. Spine (Phila Pa 1976) 1998; 23:1457-1463.

5. Bot SD, van der Waal JM, Terwee CB, van der Windt DA, Schellevis FG, Bouter LM, Dekker J. Incidence and prevalence of complaints of the neck and upper extremity in general practice. Ann Rheum Dis 2005; 64:118-123.

6. Croft PR, Lewis M, Papageorgiou AC, Thomas E, Jayson MI, MacfFarlane G], Silman AJ. Risk factors for neck pain: A longitudinal study in the general population. Pain 2001; 93:317-325.

7. Côté P, Cassidy JD, Carroll LJ, Kristman $V$. The annual incidence and course of neck pain in the general population: A population-based cohort study. Pain 2004; 112:267-273.

8. Côté $P$, Kristman V, Vidmar M, Van Eerd $D$, Hogg-Johnson S, Beaton D, Smith PM. The prevalence and incidence of work absenteeism involving neck pain: A cohort of Ontario lost-time claimants. Spine (Phila Pa 1976) 2008; 33:S192-S198.

9. Côté $P$, van der Velde G, Cassidy JD, Carroll LJ, Hogg-Johnson S, Holm LW, Carragee EJ, Haldeman S, Nordin M, Hurwitz EL, Guzman J, Peloso PM; Bone and Joint Decade 2000-2010 Task Force on Neck Pain and Its Associated Disorders. The burden and determinants of neck pain in workers. Results of the Bone and Joint Decade 2000-2010 Task Force on Neck Pain and Its Associated
Disorders. Spine (Phila Pa 1976) 2008; 33:S60-S74.

10. Vos CJ, Verhagen AP, Passchier J, Koes $\mathrm{BW}$. Clinical course and prognostic factors in acute neck pain: An inception cohort study in general practice. Pain Med 2008; 9:572-580.

11. U.S. Burden of Disease Collaborators. The state of US health, 1990-2010: Burden of disease, injuries, and risk factors. JAMA 2013; 310:591-608.

12. Martin BI, Deyo RA, Mirza SK, Turner JA, Comstock BA, Hollingworth W, Sullivan SD. Expenditures and health status among adults with back and neck problems. JAMA 2008; 299:656-664. Erratum in: JAMA 2008; 299:2630.

13. Martin BI, Turner JA, Mirza SK, Lee MJ, Comstock BA, Deyo RA. Trends in health care expenditures, utilization, and health status among US adults with spine problems, 1997-2006. Spine (Phila Pa 1976) 2009; 34:2077-2084.

14. Institute of Medicine (IOM). Relieving Pain in America: A Blueprint for Transforming Prevention, Care, Education, and Research. The National Academies Press, Washington, DC, June 29, 2011.

www.iom.edu/ /media/Files/Report\%20 Files/2011/Relieving-Pain-in-America-ABlueprint-for-Transforming-PreventionCare-Education-Research/Pain\%2oResearch\%202011\%20Report\%20Brief.pdf

15. Gaskin DJ, Richard P. The economic costs of pain in the United States. J Pain 2012; 13:715-724.

16. Social Security Administration. Annual Statistical Report on the Social Security Disability Insurance Program, 2011 Baltimore, MD, Office of Research Evaluation and Statistics, 2011.

www.ssa.gov/policy/docs/statcomps/di_ asr/2011/di_asr11.pdf

17. Manchikanti L, Abdi S, Atluri S, Benyamin RM, Boswell MV, Buenaventura RM, Bryce DA, Burks PA, Caraway DL, Calodney AK, Cash KA, Christo PJ, Cohen SP, Colson J, Conn A, Cordner HJ, Coubarous $S$, Datta $S$, Deer TR, Diwan SA, Falco FJE, Fellows B, Geffert SC, Grider JS, Gupta S, Hameed H, Hameed M, Hansen $H$, Helm II S, Janata JW, Justiz R, Kaye AD, Lee M, Manchikanti KN, McManus CD, Onyewu O, Parr AT, Patel VB, Racz GB, Sehgal N, Sharma M, Simopoulos TT, Singh V, Smith HS, Snook LT, Swicegood J, Vallejo R, Ward SP, Wargo BW, Zhu J, Hirsch JA. An update of comprehensive evidence-based guidelines for interventional techniques of chronic spinal pain: Part II: Guidance and recommendations. Pain Physician 2013; 16:S49-S283

18. Diwan SA, Manchikanti L, Benyamin RM, Bryce DA, Geffert S, Hameed H, Sharma ML, Abdi S, Falco FJE. Effectiveness of cervical epidural injections in the management of chronic neck and upper extremity pain. Pain Physician 2012; 15:E405-E434.

19. Bogduk N. The anatomy and pathophysiology of neck pain. Phys Med Rehabil Clin N Am 2011; 22:367-382.

20. Van Zundert J, Huntoon M, Patijn J, Lataster A, Mekhail N, van Kleef M; Pain Practice. 4. Cervical radicular pain. Pain Pract 2010; 10:1-17.

21. Schoenfeld AJ, George AA, Bader JO, Caram PM Jr. Incidence and epidemiology of cervical radiculopathy in the United States military: 2000 to 2009. J Spinal Disord Tech 2012; 25:17-22.

22. Manchikanti L, Falco FJE, Benyamin RM. Neck and cervical radicular pain. In: Manchikanti L, Christo PJ, Trescot AM, Falco FJE (eds). Clinical Aspects of Pain Medicine and Interventional Pain Management: A Comprehensive Review. ASIPP Publishing, Paducah, KY, 2011, pp 35-60.

23. Bogduk N. Pathology. In: Medical Management of Acute Cervical Radicular Pain: An Evidence-Based Approach. 1st Ed. Cambridge Press, Newcastle, 1999, pp 13-18.

24. Karadimas SK, Klironomos G, Papachristou DJ, Papanikolaou S, Papadaki E, Gatzounis G. Immunohistochemical profile of NF- $\mathrm{AB} / \mathrm{p} 50, \mathrm{NF}-\mathrm{QB} / \mathrm{p} 65$, MMP-9, MMP-2, and u-PA in experimental cervical spondylotic myelopathy. Spine (Phila Pa 1976) 2013; 38:4-10.

25. Vos C, Verhagen A, Passchier J, Koes B. Management of acute neck pain in general practice: a prospective study. $\mathrm{Br} \mathrm{J}$ Gen Pract 2007; 57:23-28.

26. Oglesby M, Fineberg SJ, Patel AA, Pelton $M A$, Singh K. Epidemiological trends in cervical spine surgery for degenerative diseases between 2002 and 2009. Spine (Phila Pa 1976) 2013; 38:1226-1232.

27. Boselie TF, Willems PC, van Mameren $H$, de Bie RA, Benzel EC, van Santbrink $\mathrm{H}$. Arthroplasty versus fusion in singlelevel cervical degenerative disc disease: A Cochrane Review. Spine (Phila Pa 1976) 2013; 38:E1096-E1107.

28. Peloso PMJ, Gross A, Haines T, Trinh $\mathrm{K}$, Goldsmith $\mathrm{CH}$, Burnie Sj; Cervical Overview Group. Medicinal and injection therapies for mechanical neck 
disorders. Cochrane Database Syst Rev 2007; 3:CDoo0319.

29. Manchikanti L, Pampati V, Falco FJE, Hirsch JA. Growth of spinal interventional pain management techniques: Analysis of utilization trends and Medicare expenditures 2000 to 2008. Spine (Phila Pa 1976) 2013; 38:157-168.

30. Manchikanti L, Falco FJE, Singh V, Pampati V, Parr AT, Benyamin RM, Fellows B, Hirsch JA. Utilization of interventional techniques in managing chronic pain in the Medicare population: Analysis of growth patterns from 2000 to 2011. Pain Physician 2012; 15:E969-E982.

31. Manchikanti L, Pampati V, Falco FJE, Hirsch JA. Assessment of the growth of epidural injections in the Medicare population from 2000 to 2011. Pain Physician 2013; 16:E349-E364.

32. Verhagen AP, van Middelkoop M, Rubinstein SM, Ostelo R, Jacobs W, Peul W, Koes BW, van Tulder MW. Effect of various kinds of cervical spinal surgery on clinical outcomes: A systematic review and meta-analysis. Pain 2013. [Epub ahead of print]

33. Wang TY, Lubelski D, Abdullah KG, Steinmetz MP, Benzel EC, Mroz TE. Rates of anterior cervical discectomy and fusion after initial posterior cervical foraminotomy. Spine ] 2013. [Epub ahead of print]

34. Fineberg SJ, Oglesby M, Patel AA, Pelton MA, Singh K. Outcomes of cervical spine surgery in teaching and nonteaching hospitals. Spine (Phila Pa 1976) 2013; 38:1089-1096.

35. Helgeson MD, Albert TJ. Surgery for failed cervical spine reconstruction. Spine (Phila Pa 1976). 2012; 37: E323-E327.

36. Patil PG, Turner DA, Pietrobon R. National trends in surgical procedures for degenerative cervical spine disease: 1990-2000. Neurosurgery 2005; 57:753-758.

37. Manchikanti L, Cash KA, Pampati V, Wargo BW, Malla Y. The effectiveness of fluoroscopic cervical interlaminar epidural injections in managing chronic cervical disc herniation and radiculitis: Preliminary results of a randomized, double-blind, controlled trial. Pain Physician 2010; 13:223-236.

38. Manchikanti L, Cash KA, Pampati V, Wargo BW, Malla Y. Management of chronic pain of cervical disc herniation and radiculitis with fluoroscopic cervical interlaminar epidural injections. Int J Med Sci 2012; 9:424-434.
39. Castagnera L, Maurette $P$, Pointillart $V$, Vital JM, Erny P, Senegas J. Long-term results of cervical epidural steroid injection with and without morphine in chronic cervical radicular pain. Pain 1994; 58:239-243.

40. Stav A, Ovadia L, Sternberg A, Kaadan M, Weksler N. Cervical epidural steroid injection for cervicobrachialgia. Acta Anaesthesiol Scand 1993; 37:562-566.

41. Pasqualucci A, Varrassi G, Braschi A, Peduto VA, Brunelli A, Marinangeli $F$, Gori F, Colò F, Paladini A, Mojoli F. Epidural local anesthetic plus corticosteroid for the treatment of cervical brachial radicular pain: Single injection versus continuous infusion. Clin J Pain 2007; 23:551-557.

42. Altman DG, Schulz KF, Moher D, Egger M, Davidoff F, Elbourne D, Gøtzsche PC, Lang T; CONSORT GROUP (Consolidated Standards of Reporting Trials). The revised CONSORT statement for reporting randomized trials: Explanation and elaboration. Ann Intern Med 2001; 134:663-694.

43. Moher D, Hopewell S, Schulz KF, Montori V, Gøtzsche PC, Devereaux PJ, Elbourne D, Egger M, Altman DG. CONSORT 2010 explanation and elaboration: Updated guidelines for reporting parallel group randomised trials. BMJ 2010; 340:c869.

44. Carragee EJ. The rise and fall of the "minimum clinically important difference." Spine ] 2010; 10:283-284.

45. Carragee EJ, Chen I. Minimum acceptable outcomes after lumbar spinal fusion. Spine J 2010; 10:313-320.

46. Gatchel RJ, Mayer TG, Choi Y, Chou R. Validation of a consensus-based minimal clinically important difference (MCID) threshold using an objective functional external anchor. Spine J 2013; 13:889-893.

47. Parker SL, Adogwa O, Mendenhall SK, Shau DN, Anderson WN, Cheng JS, Devin CJ, McGirt MJ. Determination of minimum clinically important difference $(M C I D)$ in pain, disability, and quality of life after revision fusion for symptomatic pseudoarthrosis. Spine J 2012; 12:1122-1128.

48. Copay AG, Subach BR, Glassman SD, Polly DW Jr, Schuler TC. Understanding the minimum clinically important difference: A review of concepts and methods. Spine ] 2007; 7:541-546.

49. Cleland JA, Childs JD, Whitman JM. Psychometric properties of the Neck Disability Index and Numeric Pain Rat- ing Scale in patients with mechanical neck pain. Arch Phys Med Rehabil 2008; 89:69-74.

50. Pietrobon R, Coeytaux RR, Carey TS, Richardson WJ, DeVellis RF. Standard scales for measurement of functional outcome for cervical pain or dysfunction: A systematic review. Spine (Phila Pa 1976) 2002; 27:515-522.

51. Pereira J, Lawlor P, Vigano A, Dorgan $M$, Bruera E. Equianalgesic dose ratios for opioids. A critical review and proposals for long-term dosing. J Pain Symptom Manage 2001; 22:672-687.

52. Browner WS, Newman TB, Cummings SR, Hulley SB. Estimating sample size and power. In: Hulley SB, Cummings SR, Browner WS, Grady D, Hearst N, Newman TB (eds). Designing Clinical Research: An Epidemiologic Approach. 2nd ed. Lippincott, Williams \& Wilkins, Philadelphia, 2001, pp 65-84.

53. Park MS, Moon SH, Lee HM, Kim SW, Kim TH, Suh BK, Riew KD. The natural history of degenerative spondylolisthesis of the cervical spine with 2- to 7-year follow-up. Spine (Phila Pa 1976) 2013; 38:E205-E210.

54. Kang JD, Georgescu HI, McIntyre-Larkin L, Stefanovic-Racic M, Evans $\mathrm{CH}$. Herniated cervical intervertebral discs spontaneously produce matrix metalloproteinases, nitric oxide, interleukin-6 and prostaglandin E2. Spine (Phila Pa 1976) 1995; 20:2373-2378.

55. Stout A. Epidural steroid injections for cervical radiculopathy. Phys Med Rehabil Clin N Am 2011; 22:149-159.

56. Huston CW. Cervical epidural steroid injections in the management of cervical radiculitis: interlaminar versus transforaminal. A review. Curr Rev Musculoskelet Med 2009; 2:30-42.

57. Candido KD, Knezevic N. Cervical epidural steroid injections for the treatment of cervical spinal (neck) pain. Curr Pain Headache Rep 2013; 17:314.

58. Manchikanti L, Cash KA, Pampati V, Malla Y. Fluoroscopic cervical epidural injections in chronic axial or disc-related neck pain without disc herniation, facet joint pain, or radiculitis. J Pain Res 2012; 5:227-236.

59. Lee SH, Kim KT, Kim DH, Lee BJ, Son ES, Kwack YH. Clinical outcomes of cervical radiculopathy following epidural steroid injection: a prospective study with follow-up for more than 2 years. Spine (Phila Pa 1976) 2012; 37:1041-1047.

6o. Kranz PG, Raduazo PA. Technique for CT 
fluoroscopy-guided cervical interlaminar steroid injections. AJR Am J Roentgenol 2012; 198:675-677.

61. Usta B, Muslu B, DemircioDlu RI, Sert H, Gözdemir M, Karabayirli S. Cervical epidural steroid injections for symptomatic disc herniations. Agri 2012; 24:130-134.

62. Beyaz SG, Eman A. Fluoroscopy guided cervical interlaminar steroid injections in patients with cervical pain syndromes: A retrospective study. J Back Musculoskelet Rehabil 2013; 26:85-91.

63. Shakir A, Ma V, Mehta B. Prediction of therapeutic response to cervical epidural steroid injection according to distribution of radicular pain. Am J Phys Med Rehabil 2011; 90:917-922.

64. Scanlon GC, Moeller-Bertram T, Romanowsky SM, Wallace MS. Cervical transforaminal epidural steroid injections: More dangerous than we think? Spine (Phila Pa 1976) 2007; 32:1249-1256.

65. Rathmel JP, Benzon HT. Transforaminal injection of steroids: Should we continue? Reg Anesth Pain Med 2004; 29:297-299.

66. Tiso RL, Cutler T, Catania JA, Whalen K. Adverse central nervous system sequelae after selective transforaminal block: The role of corticosteroids. Spine J 2004; 4:468-474.

67. Brouwers PJ, Kottink EJ, Simon MA, Prevo RL. A cervical anterior spinal artery syndrome after diagnostic blockade of the right C6-nerve root. Pain 2001; 91:397-399.

68. Wallace MA, Fukui MB, William RL, Ku A, Baghai P. Complications of cervical selective nerve root blocks performed with fluoroscopic guidance. AJR Am J Roentgenol 2007; 188:1218-1221.

69. Rathmell JP, Aprill C, Bogduk N. Cervical transforaminal injection of steroids. Anesthesiology 2004; 100:1595-1600.

70. Manchikanti L, Malla Y, Wargo BW, Cash KA, Pampati V, Fellows B. A prospective evaluation of complications of 10,000 fluoroscopically directed epidural injections. Pain Physician 2012; 15:131-140.

71. Abbasi A, Malhotra G, Malanga G, Elovic EP, Kahn S. Complications of interlaminar cervical epidural steroid injections: A review of the literature. Spine (Phila Pa 1976) 2007; 32:2144-2151.

72. Hodges SD, Castleberg RL, Miller T, Ward R, Thornburg C. Cervical epidural steroid injection with intrinsic spinal cord damage. Two case reports. Spine (Phila Pa 1976) 1998; 23:2137-2142.
73. Kaplan MS, Cunniff J, Cooke J, Collins JG. Intravascular uptake during fluoroscopically guided cervical interlaminar steroid injection at C6-7: A case report. Arch Phys Med Rehabil 2008; 89:553-558.

74. McGrath JM, Schaefer MP, Malkamaki DM. Incidence and characteristics of complications from epidural steroid injections. Pain Med 2011; 12:726-731.

75. Shanthanna H, Park J. Acute epidural haematoma following epidural steroid injection in a patient with spinal stenosis. Anaesthesia 2011; 66:837-839.

76. Manchikanti L, Pampati V, Singh V, Falco FJE. Assessment of the escalating growth of facet joint interventions in the Medicare population in the United States from 2000 to 2011. Pain Physician 2013; 16: $\mathrm{E}_{365}$-E378.

77. Cluff R, Mehio AK, Cohen SP, Chang Y, Sang CN, Stojanovic MP. The technical aspects of epidural steroid injections: A national survey. Anesth Analg 2002; 95:403-408.

78. Stojanovic MP, Vu TN, Caneris O, Slezak J, Cohen SP, Sang CN. The role of fluoroscopy in cervical epidural steroid injections: An analysis of contrast dispersal patterns. Spine (Phila Pa 1976) 2002; 27:509-514.

79. Ho PS, Yu SW, Sether LA, Wagner M, Ho KC, Haughton VM. Ligamentum flavum: Appearance on sagittal and coronal MR images. Radiology 1988; 168:469-472.

8o. Lirk P, Kolbitsch C, Putz G, Colvin J, Colvin $\mathrm{HP}$, Lorenz I, Keller C, Kirchmair L, Rieder J, Moriggl B. Cervical and high thoracic ligamentum flavum frequently fails to fuse in the midline. Anesthesiology 2003; 99:1387-1390.

81. Chou R, Atlas SJ, Loeser JD, Rosenquist RW, Stanos SP. Guideline warfare over interventional therapies for low back pain: Can we raise the level of discourse? J Pain 2011; 12:833-839.

82. Manchikanti L, Benyamin RM, Falco FJE, Caraway DL, Datta S, Hirsch JA. Guidelines warfare over interventional techniques: Is there a lack of discourse or straw man? Pain Physician 2012; 15:E1-E26.

83. Byrod G, Otani K, Brisby H, Rydevik B, Olmarker K. Methylprednisolone reduces the early vascular permeability increase in spinal nerve roots induced by epidural nucleus pulposus application. J Orthop Res 2000; 18:983-987.

84. Lee HM, Weinstein JN, Meller ST, Hayashi N, Spratt KF, Gebhart GF. The role of steroids and their effects on phospholipase A2: an animal model of radiculopathy. Spine (Phila Pa 1976) 1998; 23:1191-1196.

85. Alimasi W, Sawaji Y, Endo K, Yorifuji M, Suzuki H, Kosaka T, Shishido T, Yamamoto K. Regulation of nerve growth factor by anti-inflammatory drugs, a steroid, and a selective cyclooxygenase 2 inhibitor in human intervertebral disc cells stimulated with interleukin-1. Spine (Phila Pa 1976) 2013; 38:1466-1472.

86. Minamide A, Tamaki T, Hashizume H, Yoshida M, Kawakami M, Hayashi N. Effects of steroids and lipopolysaccharide on spontaneous resorption of herniated intervertebral discs: An experimental study in the rabbit. Spine (Phila Pa 1976) 1998; 23:870-876.

87. Hayashi N, Weinstein JN, Meller ST, Lee HM, Spratt KF, Gebhart GF. The effect of epidural injection of betamethasone or bupivacaine in a rat model of lumbar radiculopathy. Spine (Phila Pa 1976) 1998; 23:877-885.

88. Tachihara H, Sekiguchi M, Kikuchi S, Konno S. Do corticosteroids produce additional benefit in nerve root infiltration for lumbar disc herniation. Spine (Phila Pa 1976) 2008; 33:743-747.

89. Sato C, Sakai A, Ikeda Y, Suzuki H, Sakamoto $A$. The prolonged analgesic effect of epidural ropivacaine in a rat model of neuropathic pain. Anesth Analg 2008; 106:313-320.

90. Pasqualucci A. Experimental and clinical studies about the preemptive analgesia with local anesthetics. Possible reasons of the failure. Minerva Anestesiol 1998; 64:445-457.

91. Arner S, Lindblom U, Meyerson BA, Molander $C$. Prolonged relief of neuralgia after regional anesthetic block. A call for further experimental and systematic clinical studies. Pain 1990; 43:287-297.

92. Manchikanti L, Singh V, Falco FJE, Cash KA, Pampati V. Evaluation of lumbar facet joint nerve blocks in managing chronic low back pain: A randomized, double-blind, controlled trial with a 2-year follow-up. Int J Med Sci 2010; 7:124-135.

93. Manchikanti L, Singh V, Falco FJE, Cash KA, Pampati V, Fellows B. The role of thoracic medial branch blocks in managing chronic mid and upper back pain: A randomized, double-blind, activecontrol trial with a 2-year follow-up. Anesthesiol Res Pract 2012; 2012:585806.

94. Manchikanti L, Helm II S, Hirsch JA. The 
evolution of the Patient-Centered Outcome Research Institute. J Neurointervent Surg 2012; 4:157-162.

95. Feudtner C, Schreiner M, Lantos JD. Risks (and benefits) in comparative effectiveness research trials. $N$ Engl J Med 2013 [Epub ahead of print].

96. Manchikanti L, Falco FJE, Benyamin RM, Helm II S, Singh V, Hirsch JA. Value-based interventional pain management: A review of Medicare national and local coverage determination policies. Pain Physician 2013; 16:E145-E180.

97. Manchikanti L, Singh V, Cash KA, Pampati V, Damron KS, Boswell MV. A randomized, controlled, double-blind trial of fluoroscopic caudal epidural injections in the treatment of lumbar disc herniation and radiculitis. Spine (Phila Pa 1976) 2011; 36:1897-1905.

98. Manchikanti L, Singh V, Cash KA, Pampati V, Falco FJE. The role of fluoroscopic interlaminar epidural injections in managing chronic pain of lumbar disc herniation or radiculitis: A randomized, double-blind trial. Pain Pract 2012 Dec 27. [Epub ahead of print]

99. Tunis SR, Stryer DB, Clancy CM. Practical clinical trials. Increasing the value of clinical research for decision making in clinical and health policy. JAMA 2003; 290:1624-1632.

100. International Conference on Harmonisation of Technical Requirements for Registration of Pharmaceuticals for Hu- man Use. ICH Harmonised Tripartite Guideline. Choice of Control Group and Related Issues in Clinical Trials Eıo. July 20, 2000.

101. Iversen T, Solberg T, Romner B, Wilsgaard T, Twisk J, Anke A, Nygaard O, Hasvold T, Ingebrigtsen T. Effect of caudal epidural steroid or saline injection in chronic lumbar radiculopathy: Multicentre, blinded, randomised controlled trial. BM] 2011; 343:d 5278 .

102. Carette $S$, Leclaire R, Marcoux S, Morin F, Blaise GA, St-Pierre A, Truchon R, Parent $F$, Levésque J, Bergeron $V$, Montminy $P$, Blanchette $C$. Epidural corticosteroid injections for sciatica due to herniated nucleus pulposus. N Engl J Med 1997; 336:1634-1640.

103. Karppinen J, Malmivaara A, Kurunlahti $M$, Kyllönen E, Pienimäki T, Nieminen P, Ohinmaa A, Tervonen O, Vanharanta $H$. Periradicular infiltration for sciatica: A randomized controlled trial. Spine (Phila Pa 1976) 2001; 26:1059-1067.

104. Ghahreman A, Ferch R, Bogduk N. The efficacy of transforaminal injection of steroids for the treatment of lumbar radicular pain. Pain Med 2010; 11:1149-1168.

105. Pinto RZ, Maher CG, Ferreira ML, Hancock M, Oliveira VC, McLachlan AJ, Koes $\mathrm{B}$, Ferreira $\mathrm{PH}$. Epidural corticosteroid injections in the management of sciatica: A systematic review and meta-analysis. Ann Intern Med 2012; 157:865-877.
106. Manchikanti L, Falco FJE, Hirsch JA. Epidural corticosteroid injections in the management of sciatica. Ann Intern Med 2012; 157:865-877; online comment posted March 29, 2013.

107. Kaptchuk TJ, Friedlander E, Kelley JM, Sanchez MN, Kokkotou E, Singer JP, Kowalczykowski M, Miller FG, Kirsch I, Lembo AJ. Placebos without deception: A randomized controlled trial in irritable bowel syndrome. PLOS ONE 2010; 5:e15591.

108. Howick J, Friedemann C, Tsakok M, Watson R, Tsakok T, Thomas J, Perera R, Fleming $S$, Heneghan C. Are treatments more effective than placebos? A systematic review and meta-analysis. PLoS One 2013; 8:e62599.

109. Howick J, Bishop FL, Heneghan, Wolstenholme J, Stevens S, Hobbs FDR, Lewith G. Placebo use in the United Kingdom: Results from a national survey of primary care practitioners. PLOS One 2013; 8:e58247.

110. Gerdesmeyer L, Wagenpfeil S, Birkenmaier C, Veihelmann A, Hauschild M, Wagner K, Al Muderis M, Gollwitzer H, Diehl P, Toepfer A. Percutaneous epidural lysis of adhesions in chronic lumbar radicular pain: A randomized double-blind placebo controlled trial. Pain Physician 2013; 16:185-196. 